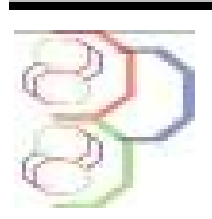

\title{
Indigenous knowledge associated with the production of starters culture used to produce Beninese opaque sorghum beers
}

\author{
N’tcha C1, Adéyèmi AD², Kayodé APP2, Vieira-Dalodé G³, Agbobatinkpo BP³, Codjia JTC4, Baba- \\ Moussa $\mathrm{L}^{1}$ \\ 1. Laboratoire de Biologie et Typage Moléculaire en Microbiologie; Faculté des Sciences et Techniques/Université \\ d'Abomey-Calavi. 05 BP 1604 Cotonou Bénin. \\ 2. Laboratoire de Valorisation et de Gestion de la Qualité de Bio ingrédients Alimentaires. Faculté des Sciences \\ Agronomiques/ (LaBio), DNSA/FSA, Université d'Abomey-Calavi, 01 BP 526 Cotonou, Benin. \\ 3. Laboratoire de Physico-chimie des Aliments Faculté des Sciences Agronomiques/Université d'Abomey-Calavi, 01 \\ BP 526 Cotonou, Bénin \\ 4. Laboratoire de recherche en Ecologie Animale et Zoogéographie Faculté des Sciences Agronomiques/Université \\ d'Abomey-Calavi, 01 BP 526 Cotonou, Bénin. \\ * Corresponding Author Tel: (+229) 97870734, E-mail polykap@yahoo.fr
}

Original submitted in on $18^{\text {th }}$ November 2014. Published online at www.m.elewa.org on 30th April 2015 http://dx.doi.org/10.4314/jab.v88i1.7

\begin{abstract}
Objective: The present study aims to document the indigenous Knowledge associated with the production of starters culture to be used for opaque sorghum beers manufacturing in Benin

Methodology and results: A quantitative survey was carried out in the central and the northern regions of Benin. A total of ninety (90) processors of traditional beers were interviewed using a semi-structured questionnaire. The collected information was related to the processing method of the starters' production, its shelf life as well as sociodemographic data on the producers. Five types of starters were identified during this investigation. Apart from the beer itself which can be used as starter, we can distinguish kpètè-kpètè; the fermentation calabash, the bag and the belt of fermentation. Among them, the fermentation calabash was mostly used by $74 \%(67 / 90)$ of beer producers followed by kpètè-kpètè $21 \%(19 / 90)$. In some cases, these starters were used in association with each other to speed up the fermentation process. All the producers were women with an average age of 38 years old. Among those women, about $73 \%$ (66/90) produce and sell the beer as principal activity. According to $56 \%(51 / 90)$ of the producers, the quality of the manufactured beer depends on the quality of the starter used. Many other factors such as the sorghum variety, the brewing technique can also affect the beer quality. It is reported by $70 \%$ (63/90) of producers that the storage duration reduces the fermentative ability of kpètè-kpètè. Some health-related properties such as the treatment of diarrhoea have been attributed to kpètè-kpètè by $73 \%(66 / 90)$ of the producers interviewed.

Conclusion and application of results: the fermentation calabash is the most used starter by traditional beer producers because of the quality of the derived beer. The kpètè-kpètè comes in the second position but possesses the advantage of being used by people to cure humans and animals diseases. Further
\end{abstract}




\section{N'tcha et al. . J. Appl. Biosci. Indigenous knowledge associated with the production of starters culture used}

to produce Beninese opaque sorghum beers

investigations are needed to identify the functional microorganisms involved in the kpètè-kpètè to better understanding its health-related attributes.

Keywords: Indigenous Knowledge, tchoukoutou, kpètè-kpètè, fermentation, Benin.

\section{INTRODUCTION}

Sorghum bicolor is the fifth most highly produced crop with a total production of about 58 million tons in 2012 (FAO, 2014). Sorghum is especially cultivated in hot and arid regions of the world including Benin. The malting of sorghum is a widespread traditional practice in West Africa. It is used to produce fermented and unfermented beverages or incorporated into infant cereals meals. Indeed, the sorghum malt is one of the main raw materials used to prepare various traditional alcoholic beverages in West Africa: dolo (Mali, Burkina Faso), tchoukoutou and chakpalo (Benin, Togo, Niger and Côte d'Ivoire), burukutu or pito (Nigeria, Ghana), dam (Togo), (Odunfa, 1985; Glover et al., 2005; Kayodé et al., 2005, Osseyi et al., 2011). It is also used to produce non-alcoholic beverages like gowé in Benin (MichodjèhounMestres et al 2005). In addition, it has a wide range of other applications that are being explored with worldwide interest in renewable resources. There are some variants of Opaque sorghum beers of Benin including tchololo, koutouman (both known as tchoukoutou) and tchakpalo. These beers play a significant role in the household livelihood and food security in northern Benin where they are highly prepared and consumed. Tchoukoutou is sold as street food at some special popular place (Greppi et al., 2013). These places of huge conviviality are also called cabarets. In the Northern part of Benin, tchoukoutou is currently used in religious ceremonies and in most of the traditional rituals (Kayodé et al 2005). The manufacturing process of the beverage can be divided in three steps: the malting (soaking,

\section{MATERIAL AND METHODS}

Study area and sampling: The study was conducted in three departments of Benin namely Atacora, Borgou, Alibori; based on their rich tradition in the production and consumption of the opaque sorghum beers. In the department of Atacora located in the Northern-West of Benin, three (3) communities were investigated i.e. Natitingou (10¹8'24" N; $\left.1^{\circ} 22^{\prime} 30^{\prime \prime} E\right)$, Boukoumbé germination, sun drying), the brewing (mashing, boiling, filtration) and the fermentation (Haggblade and Holzapfel, 1989). The materials used for the beer processing remain basic and are composed of large jars for mashing, cooking pots, and a basket or a piece of cloth for filtering. In general, the setting and processing conditions do not guarantee the sanitary safety of the product (Dahouenon et al 2012). Therefore, depending on the geographic location of the manufacturers, variations may occur in one or more steps during the cooking process (Odunfa, 1985; Haggblade and Holzapfel, 1989). During the fermentation process, producers often used the traditional starter called kpètè-kpètè in Bariba, a local language (Kayode et al., 2005). The tchoukoutou starter is known to contain lactic acid bacteria and yeasts (Kayode et al., 2006). Some of the microorganisms isolated from this starter are reported to have a probiotic activity (Kayode et al., 2012) because they are reported in the cure of some opportunistic infections. The probiotic effect can be noted not only in human beings but also in the diets of animals such as chickens (Kabir et al., 2004) by counteracting stresses (Cavazzoni et al., 1998; Mahajan et al., 1999; Cortes et al., 2000; Gunes et al., 2001; Shoeib and Madian, 2002). In Benin, there are few documents on the indigenous Knowledge, and the different ferment used during the opaque beer production. The present study aims to document the indigenous knowledge associated with the production of starters culture used for the fermentation of opaque sorghum beers.

$\left(10^{\circ} 18^{\prime} 24^{\prime \prime} \mathrm{N} ; 1^{\circ} 22^{\prime} 30^{\prime \prime} \mathrm{E}\right)$ and Tanguiéta $\left(10^{\circ} 37^{\prime} 11^{\prime \prime} \mathrm{N}\right.$, $\left.1^{\circ} 15^{\prime} 52^{\prime \prime} \mathrm{E}\right)$. In the department of Borgou, located in Northern east, the communities of Parakou $\left(9^{\circ} 21^{\prime} 00^{\prime \prime} \mathrm{N}\right.$; $\left.2^{\circ} 37^{\prime} 00^{\prime \prime} \mathrm{E}\right)$, Tchaourou ( $\left.8^{\circ} 52^{\prime} 60^{\prime \prime} \mathrm{N} ; 2^{\circ} 36^{\prime} 00^{\prime \prime} \mathrm{E}\right)$ and N'Dali ( $\left.9^{\circ} 51^{\prime} 39^{\prime \prime} \mathrm{N} ; 2^{\circ} 43^{\prime} 5^{\prime \prime} \mathrm{E}\right)$ were investigated. Finally, the communities of Bantè $\left(8^{\circ} 24^{\prime} 45^{\prime \prime} \mathrm{N} ; 1^{\circ} 53^{\prime} 33^{\prime \prime} \mathrm{E}\right)$, Dassa ( $\left.7^{\circ} 45^{\prime} 00^{\prime \prime} \mathrm{N} ; 2^{\circ} 10^{\prime} 52^{\prime \prime} \mathrm{E}\right)$ and Glazoué $\left(7^{\circ} 58^{\prime} 00^{\prime \prime} \mathrm{N}\right.$; 


\section{N'tcha et al. . J. Appl. Biosci. Indigenous knowledge associated with the production of starters culture used}

to produce Beninese opaque sorghum beers

$2^{\circ} 18^{\prime} 00^{\prime \prime}$ E) were investigated in Colline department located in the centre of the country. Ten (10) producers were interviewed by community amounting to ninety (90) processors for the whole study the processors were selected based on their rich beer brewing tradition.

Data collection: The survey was performed using a rapid appraisal investigation (RAl) and a quantitative survey method. The rapid appraisal investigation was performed by a series of semi-structured and informal interviews with tchoukoutou processors in the study area. In the Three department (atacora,borgou, colline), thirty(30) processors per department(Atacora,Borgou, Collines) were selected. The second level is nine (9) municipalities (Natitingou Tanguiéta, Boukoumbé, Parakou, N'dali, Tchaourou, Glazoué, Bantè Dassa). The municipalities corresponding to cities. Ten (10) Processors were randomly selected from each of nine towns. So we met nineteen (90) processors of Beninese traditional beer during this survey This approach helps to understand the indigenous knowledge on the traditional fermentation (using kpètè- kpètè) process during the production of tchoukoutou. Data generated during the RAI were used to design the questionnaire used for the quantitative survey. The data collected related to socio-demographic characteristics of the subjects (age, sex, origin, ethnic group an profession), the different types of starter used to ferment African opaque beers, the preferences of processors for different type of starters, the different technics used to manufacture each type of starter, the perception of producers on the starter quality, the conservation techniques of starters, its influence on the fermentation process and indigenous knowledge on the health-related properties of the starters. We have also collected data on the producers' perception of the starter's functionality and their efficacy during the fermentation process as well as the storage technic of the starters. .

Data analysis: The descriptive statistic (frequencies, percentages, averages, was used to analyze the data. The MS EXCEL spreadsheet and the Sphinx ${ }^{2}$ Plus software were used to generate various statistics and graphs.

\section{RESULTS}

Socio-demographic characteristics: The socio-demographic characteristics of the respondents are presented in table 1.

Table 1: Socio-demographic characteristics of the respondents.

\begin{tabular}{|c|c|c|}
\hline Variables & Modality & Percentage (\%) \\
\hline \multirow{2}{*}{ Sex } & Female & 100 \\
\hline & Male & 0 \\
\hline \multirow{6}{*}{ Age } & $\leq 20$ Years old & 1.10 \\
\hline & Between 20 and 30 Years old & 18.90 \\
\hline & Between 30 and 40 Years old & 36.70 \\
\hline & Between 40 and 50 Years old & 26.70 \\
\hline & Between 50 and 60 Years old & 14.40 \\
\hline & $\geq 60$ Years old & 2.20 \\
\hline \multirow{2}{*}{ Origin } & Native & 90 \\
\hline & Migrant & 10 \\
\hline \multirow{7}{*}{ Ethnic group } & Otamari & 30 \\
\hline & Wama & 20 \\
\hline & Berba & 10 \\
\hline & Yom & 10 \\
\hline & Lokpa & 15 \\
\hline & Nagot & 5 \\
\hline & Datcha & 10 \\
\hline \multirow{5}{*}{ Profession } & Producer of tchoukoutou & 73.30 \\
\hline & Civil servant & 7.80 \\
\hline & Seamstresses & 3.30 \\
\hline & Dressing-hair & 3.30 \\
\hline & Students & 2.20 \\
\hline
\end{tabular}




\section{N'tcha et al. . J. Appl. Biosci. Indigenous knowledge associated with the production of starters culture used}

to produce Beninese opaque sorghum beers

It appears that women aged from 19 to 65 years old produce the traditional opaque beer (tchoukoutou). The producers are native of seven ethnic groups i.e. Otamari, Wama, Berba, Yom, Lokpa, Nago, Datcha. The production of the beer is the main activity for more than $73 \%$ of the women investigated whereas the others practice this activity as a secondary job. These occasional producers practiced other jobs such as servants $(7.80 \%)$, tailors $(3.3 \%)$, dressing-hair $(3.30 \%)$ and students (2.20\%).

Different types of traditional starters: According to $63.3 \%$ of the producers, there are five different types of traditional starter cultures used to ferment opaque sorghum beers. These are kpètè-kpètè, fermentation calabashes, the tchoukoutou, fermentation belt and the fermentation bag (Figure 1).

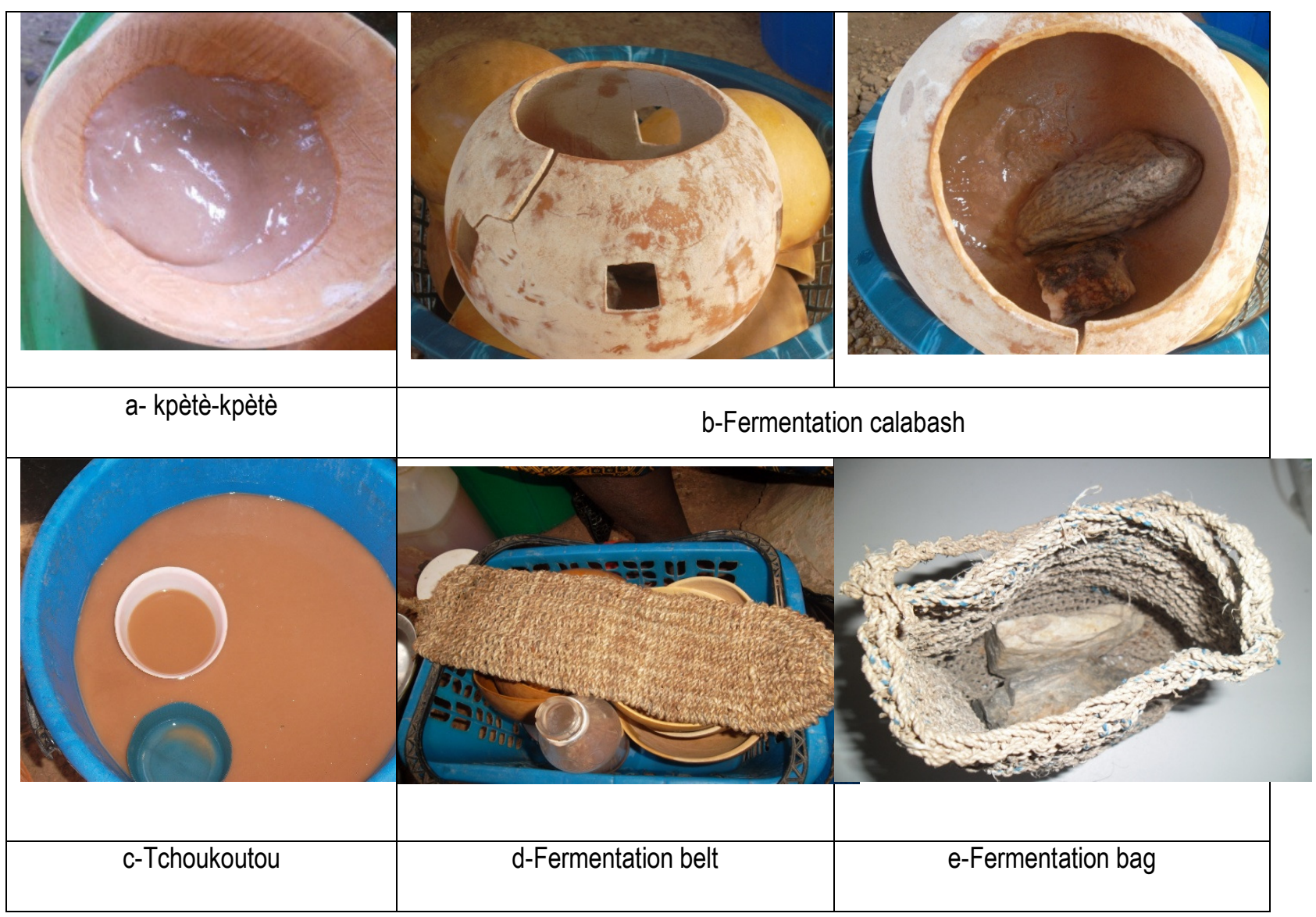

Figure 1: Illustrations of the fives starter used during the fermentation of the traditional opaque beer in Benin.

Among them, the calabash type is the most popular $(84.40 \%)$ followed by the kpètè-kpètè $(43.30 \%)$, the fermentation belt $(33.30 \%)$, the fermentation bag $(21.10 \%)$ and the beer itself $(10.00 \%)$ (Table 2). The choice of the starter varies from one department to another. Overall, the fermentation calabash was used by the producers of the three investigated departments but in variable proportions (Table 3). The kpètè-kpètè and tchoukoutou are not used in department of Atacora. In the departments of Borgou and Colline, the most used traditional starter was calabash followed by kpètè-kpètè. Several reasons were given to justify the choice of the starter type by producers. Table 4 shows the different reasons given by producers to justify the use of the fermentations techniques. The main reasons given by producers who use the Fermentation calabash were its ease of use and maintenance (32.83\%), easy of acquisition (19.40\%) and $28.4 \%$ prefer it because it gives the best quality of beverage. 
N'tcha et al. . J. Appl. Biosci. Indigenous knowledge associated with the production of starters culture used to produce Beninese opaque sorghum beers

Table 2: Frequency of citation of each fermentation technic

\begin{tabular}{lc}
\hline Fermentation technics & Frequency ${ }^{*}(\mathbf{N}=\mathbf{9 0})$ \\
\hline Fermentation calabash & $84.40 \%(76)$ \\
kpètè-kpètè alone (an earlier production) & $43.30 \%(39)$ \\
Fermentation belt & $33.30 \%(30)$ \\
Fermentation bag & $21.10 \%(19)$ \\
Tchoukoutou & $10.00 \%(09)$ \\
\hline
\end{tabular}

*: The sum of percentages exceeds 100 because of some multiple responses among the investigated population.

Table 3: Choice of fermentation type according to the study area

\begin{tabular}{lccccc}
\hline department $(\mathbf{n}=\mathbf{9 0})$ & Calabash & kpètè-kpètè & Belt & Bag & tchoukoutou \\
& & & & & \\
\hline Atacora $(\mathbf{n}=\mathbf{3 0})$ & $32.22 \%(29)$ & $0.0 \%$ & $1.11 \%(1)$ & $0.0 \%$ & $0.0 \%$ \\
Borgou $(\mathbf{n}=\mathbf{3 0})$ & $23.33 \%(21)$ & $7.78 \%(7)$ & $0.0 \%$ & $0.0 \%$ & $2.22 \%(2)$ \\
Colline $(\mathbf{n}=\mathbf{3 0})$ & $18.89 \%(17)$ & $13.33 \%(12)$ & $0.0 \%$ & $0.0 \%$ & $1.11 \%(1)$ \\
\hline TOTAL & $74.44 \%(67)$ & $21.11 \%(19)$ & $1.11 \%(1)$ & $0.0 \%$ & $3.33 \%(3)$ \\
\hline
\end{tabular}

Note: The values in the table are percentages set of 90 observations

Table 4: Reasons for the choice of a type of starter by producers

\begin{tabular}{|c|c|c|}
\hline Starter Types & Reasons & Frequency \\
\hline \multirow{6}{*}{ Calabash $(n=67)$} & Easy to use and maintain & $32.83 \%(22)$ \\
\hline & Gives better beer & $28.35 \%(19)$ \\
\hline & Easy Acquisition (available) & $19.40 \%(13)$ \\
\hline & Ferment faster and better & $14.92 \%(10)$ \\
\hline & This is what we know & $2.98 \%(2)$ \\
\hline & Less expensive & $1.49 \%(1)$ \\
\hline \multirow{3}{*}{ kpètè-kpètè (n =19) } & This is what we know & $68.42 \%(13)$ \\
\hline & Easy to use & $21.06 \%(4)$ \\
\hline & Ferment faster and better & $10.52 \%(2)$ \\
\hline \multirow{3}{*}{ tchoukoutou $(n=3)$} & This is what we know & $33.33 \%(1)$ \\
\hline & Easy to use & $33.33 \%(1)$ \\
\hline & Easy acquisition (available) & $33.33 \%(1)$ \\
\hline Belt $(n=1)$ & Easy to use and maintain & $100 \%(1)$ \\
\hline
\end{tabular}

The kpètè-kpètè is reported to be obtained from a wet deposit of previous tchoukoutou keeps for approximately one day for decantation. The fermentation calabash is obtained by using various materials such as stones ( 1 or 2), calabash (or gourd) and deposit from previous tchoukoutou production. The stones are burned, washed and introduced into the calabash (or gourd) pierced at several places. The assembly obtained was immersed for about 24 hours in a deposit obtained from a previous tchoukoutou (Figure 2). Concerning the fermentation belt and bag, the processing methods are similar and shown in the figure 3 . They are currently made by weaving creeper and diving in a well-fermented beer (or a kpètèkpètè). The belt or the bag soaked with starter was sun dried and stored away from humidity. 
N'tcha et al. . J. Appl. Biosci. Indigenous knowledge associated with the production of starters culture used to produce Beninese opaque sorghum beers

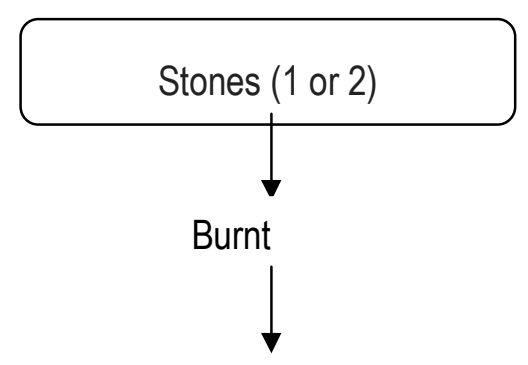

Washed

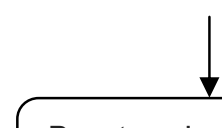

Burnt and washed stones

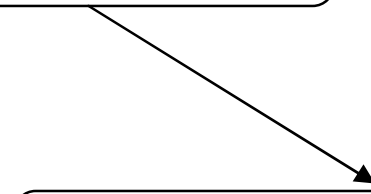

Burnt and washed stones in the clean perforated calabash / gourd

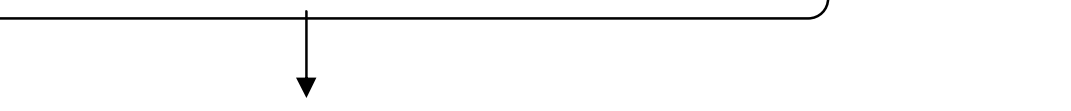

Immersion in kpètè-kpètè (1 to 2 hours)

Draining

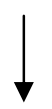

Sun Drying

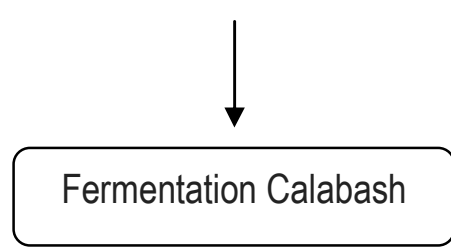

Figure 2: Diagram of the production of the fermentation calabash 
N'tcha et al. . J. Appl. Biosci. Indigenous knowledge associated with the production of starters culture used to produce Beninese opaque sorghum beers

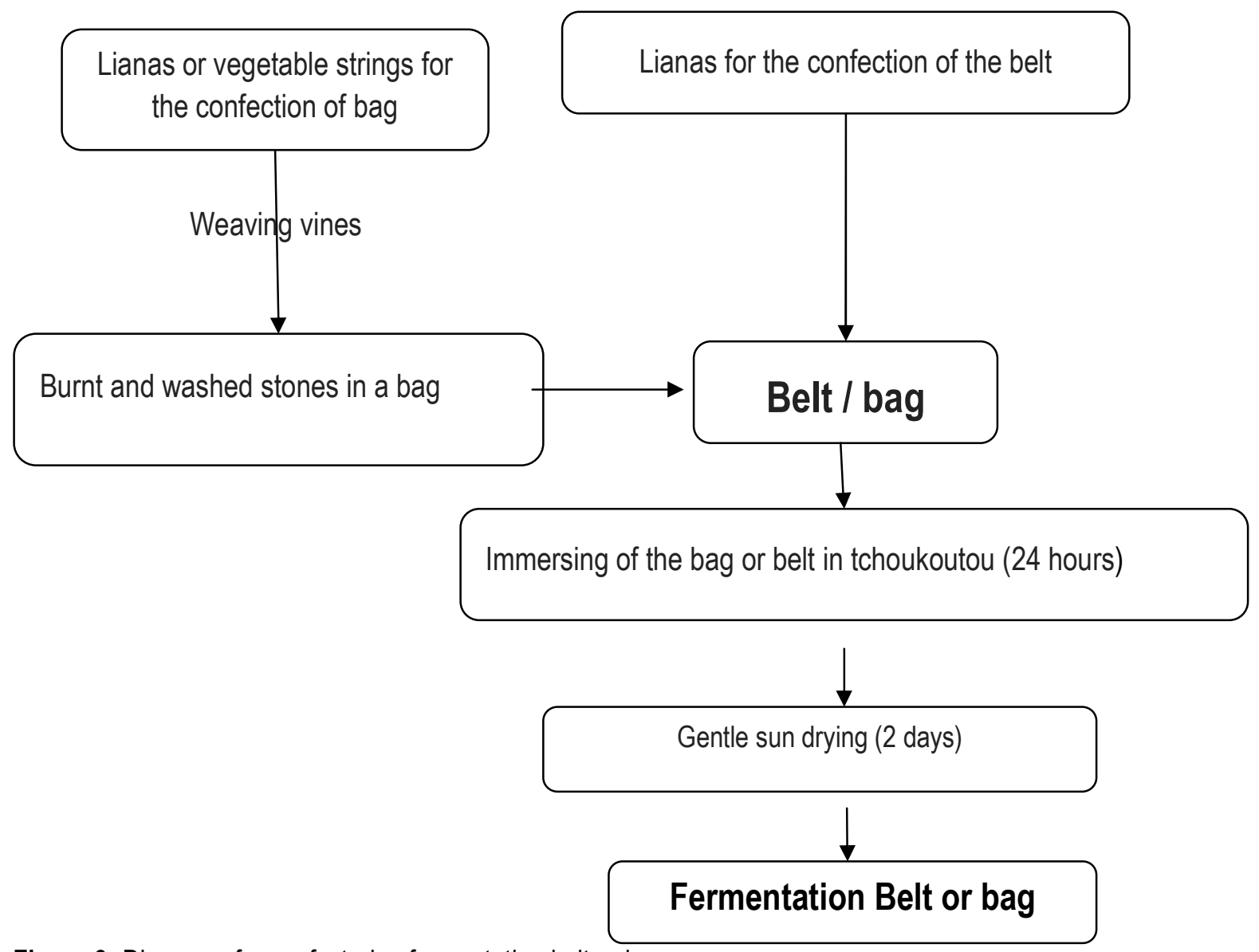

Figure 3: Diagram of manufacturing fermentation belt or bag

Producers' perception on the starters: All the women interviewed used the sediment from a previous beer. This sediment is named kpètè-kpètè in the northern part of Benin and Oshe in the central part of the country. For manufacturing of a new beer, the ferment is produced by the majority $(86.67 \%)$ of the producers themselves whereas a minority buy $(8.89 \%)$ or borrow $(4.44 \%)$ it. Nevertheless, $35.60 \%$ of the investigated women let indicated that the starter is not necessary during the fermentation process of tchoukoutou. For this type of fermentation, the wort is kept in a slightly closed container and the fermentation spontaneously started after three (03) days without any addition. However, beer derived from this type of fermentation is of poor quality (low alcohol content) compared to the beer fermented using kpètè-kpètè. Many parameters are considered by the consumers to appreciate the quality of the beer. According to the respondents, the smell, the colour and the fermentation duration constitute the major quality criteria used to appreciate the beer. The starter may have to play an important role during the fermentation. Indeed, about $57 \%$ of the producers indicated that the quality of the beer depends on the quality of starter used for its fermentation. More importantly, $75.56 \%$ of the producers indicated that the calabash gives a good quality beer and remains the most hygienic method. Nevertheless, other parameters related to the brewing technique such as the incubation temperature are other beer quality determinant. The beer produced using the kpètè-kpètè starter is also appreciated for it good quality,

Storage techniques of the traditional starters and its effect on the fermentation: The traditional starter can be kept either wet or dried. For the wet conservation (mostly for kpètè-kpètè and tchoukoutou), the starter is usually kept in a closed container with a daily renewal of the supernatant by water addition. However, this method of conservation may not exceed three (03) days, beyond this period there is a risk of visible damage of the starter. Thus, for $79 \%$ of those using the wet conservation method, after three days, the starter partly loose it fermentation ability (Table 5). In the case of the dried conservation (calabash or belt), the starters are dried for 
N'tcha et al. . J. Appl. Biosci. Indigenous knowledge associated with the production of starters culture used to produce Beninese opaque sorghum beers

about two or three days using the sun light and kept in a dry place. The dried starters can be kept for

$(70 \%)$ using the dried method revealed that after thirty approximately 30 days. The major part of the producer days of conservation, the starter must be replaced because it lost the fermentation power (Table 5).

Table 5: Influence of the storage time on the quality of the manufactured beer

\begin{tabular}{lll}
\hline Type of starter & Bad effect of the conservation time? & Efficacy time \\
\hline Wet starter (kpètè-kpètè and & Yes $(79 \%)$ & Three days \\
\cline { 2 - 3 } tchoukoutou) & No $(21 \%)$ & Seven days \\
\hline \multirow{2}{*}{ Dried starter (calabash, belt and bad) } & Yes $(70 \%)$ & One month \\
\cline { 2 - 3 } & No $(30 \%)$ & Two-three months \\
\hline
\end{tabular}

Indigenous knowledge on probiotic properties of kpètè-kpètè: Beside its socio-economic and cultural importance, kpètè-kpètè is sometimes used in traditional medicine. In this respect, $73.3 \%$ of the producers interviewed indicated that kpètè-kpètè is used in the treatment of some humans' diseases such as malaria, diarrhoea, dysentery, persistent wound and itching (Figure 4). For the treatment, the kpètè-kpètè is often taken as porridge by the patient. The major disease treated by the kpètè-kpètè is diarrhoea $(80 \%)$. The ferment is also reported to be used as a condiment in the preparation of certain sauces because it may enhance the taste to the sauce. Kpètè-kpètè is also used for the feeding of domestic's animals. It is reported to promote the growth of some animals $(71.43 \%)$ and to cure some animal's infectious diseases (7.80\%) (Figure 5).

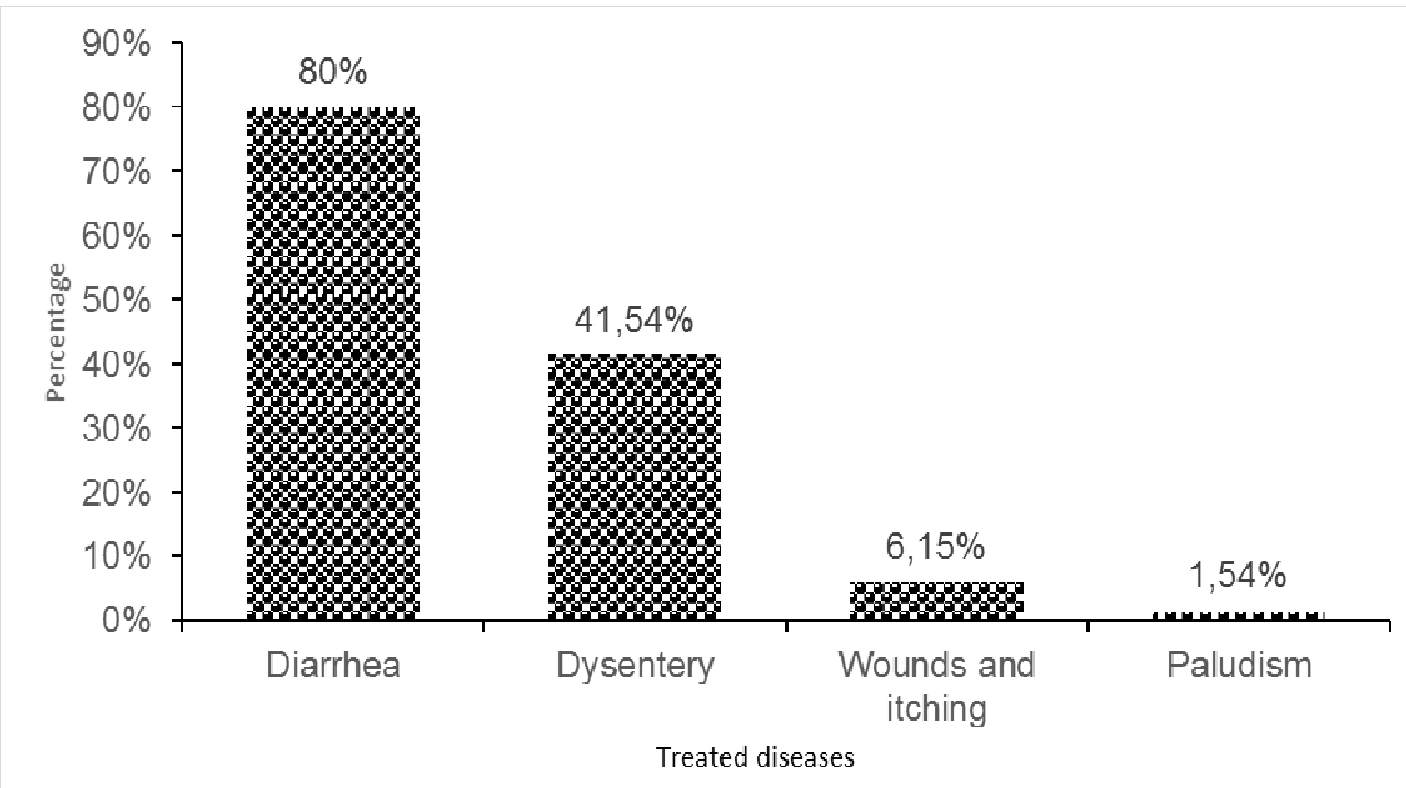

Figure 4: Tradition use of kpètè-kpètè to cure some human diseases 


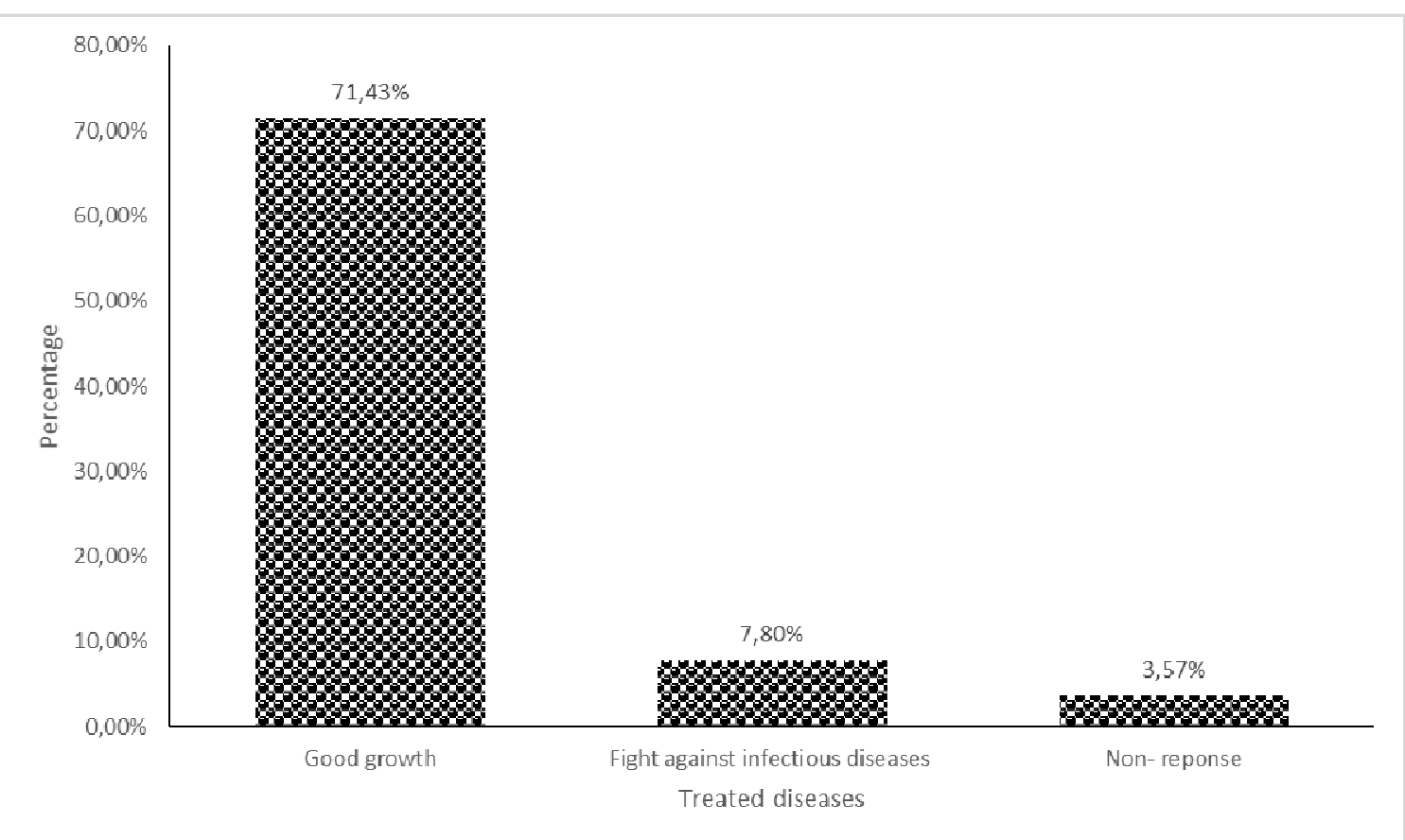

Figure 5: Effects of kpètè-kpètè (tchoukoutou deposit) on the health of domestic animals.

\section{DISCUSSION}

Young women aged from 20 to 50 years (82.3\%) exclusively produce the traditional opaque beer in Bénin. Old women (age > 50) account only for $16.6 \%$. These results corroborates findings by Djitog et al. (2002) on the production of sorghum beer bili-bili from Tchad where the majority of women beer producers have mean age between 26 and 35 years. Contrary to our finding, other studies on the local beers reported a high proportion of old processors involved on this activity (Zangué et al., 2013). This may suggest that the activity is attracting more and more younger people because it provides significant income. It generally the generated income is used to support education of children. Moreover, such activity contributes to women autonomy in their household also help them to contribute for some family charges. . Kayodé et al. (2005) reported that women for household needs use the generated income from sorghum beer selling and part of it is invested in children's education. The production of the beer is mainly made by certain sociocultural group such as Otamari, Wama, Berba, Yom and Lokpa. Indeed these ethnic groups use this beer during many traditional ceremonies. Thus, for most of the producers, they learn the process in their family. This situation explains the fact that even if the producers have another work (they occasionally produced the beer to maintain the tradition. For sorghum beer fermentation, kpètè-kpètè or oshè are mostly used. This starter is obtained from the sediment of a previous beer. Generally, the kpètè-kpètè is obtained from the processor own beer production but some time they borrow it or buy it from another producer. Though all the producers use the ferments as a starter, $35.60 \%$ of the investigated women say that the starter was not necessary during the fermentation process of the tchoukoutou. This observation let to imagine that the producer who are currently in the activity do not need to get any starter from there colleague. Thus, those who buy or borrow the kpètè-kpètè are the occasional producers. Indeed, if producers not exerting continuously the activity, they can conserve the kpètè-kpètè for a long time but the wet starter is reported not to be conserve for more than five days. According to the producers, the kpètè-kpètè will perform well during fermentation until three days of storage. After that duration, the quality of the beer is not very appreciated by the consumers. Our study showed that the kpètè-kpètè could be used alone without further processing. The different types of fermentation can be grouped in five types: the beer itself, the kpètè-kpètè fermentation belt, the fermentation bag and the fermentation calabash. The fermentation calabash is the most used among these types of starters (Table 3 ). This type of starter is preferred because it availability, use and conservation are easy and it provides a best quality of beverage. These results corroborate those of Dahouenon 


\section{N'tcha et al. . J. Appl. Biosci. Indigenous knowledge associated with the production of starters culture used}

to produce Beninese opaque sorghum beers

et al. (2012) on the stabilization of beer produced from local materials (Sorghum bicolor and Musa acuminata) by adding the essential oil of Cymbopogon citratus. Indeed, according to these authors, the quality of the beer depends on the mentioned techniques, a good hygiene practices and the conditions of the fermentation. According to the type of fermentation, the production process varies. Concerning the conservation methods, the starter can be classified in two categories; the dried ferment (calabash, belt and bad) and the wet one (kpètèkpètè and tchoukoutou). The wet starters can be conserved for 3 days maximum whereas the dried starter can be conserved for at least 30 days. This use of kpètèkpètè in traditional medicine confirm the observations made by Mensah et al. (1990) and Kimmons et al. (1999), who concluded that the fermented foods help to reduce the persistence and severity of childhood diarrhoea. In addition, Kayodé et al. (2007) reported that some of tchoukoutou consumers enjoy a well-fermented beer because they believe that such beer fight against malaria and purify the blood. These assertions suggest that the microorganisms contain in the kpètè-kpètè have probably some functional properties such as probiotic activities. Indeed, Kayodé et al. (2012) in their study on the microbial quality of kpètè-kpètè reported that the starter of

\section{CONCLUSION}

Wide ranges of starters are used for the production of the traditional beers in Benin. Among these starters, the calabash is the most used by producers because of the quality of the derived beer for a better preservation of this starter. The kpètè-kpètè comes in the second position but tchoukoutou harbour microorganisms with probiotic activity. This probiotic activity may be a possible reason for the medicinal value of kpètè-kpètè. Indeed, many probiotic microorganisms are reported to be useful in the improvement of some gastrointestinal and extra-intestinal disorders (Kotowska et al 2005; Szajewska et al 2005), inflammatory bowel disease, irritable bowel syndrome (IBS), vaginal infections and the stimulation of immune system (Szajewska et al., 2007). In addition, some lactic bacteria have been used to prevent diarrhoea caused by excessive use of antibiotics. (Szajewska et al 2005, Correa et al 2005), to threat dysbiosis (imbalance of the bacterial flora) from antibiotics (Ruszczynski et al 2008; Ruszczynski et al. 2008; Arvola et al 1999). Apart from these effects, some positive effects of probiotics microorganisms were reported on the survival of preterm infants (Lin et al., 2005; 2008; Bin-Nun et al 2005) and on liver cirrhosis (Shukla et al., 2011). Thus, taking into account these beneficial effects and it stability, kpètèkpètè can fight against opportunistic pathogens. Kpètèkpètè is also used in the feeding of domestic animals for which it may promote the growth. Thus, it can be a good alternative during the dry season characterize by the lack of fodder for domestic livestock.

possesses the advantage of being used by people to cure humans and animals diseases. It will be useful to investigate and identify the functional microorganisms involved in the kpètè-kpètè to better understanding its health-related attributes.

\section{ACKNOWLEDGE}

The authors thank the University of Abomey-Calavi for financial support to this work through the BioZoo project. Thanks are also due to the producers of traditional beers interviewed in this study for their collaboration.

\section{REFERENCES}

Anuradha S \& Rajeshwari K, 2005. Probiotics in Health and Disease. Journal Indian Academy of clinical Medicine.6: 67-72.

Arvola T, Laiho K, Torkkeli S, 1999. Prophylactic Lactobacillus $G G$ reduces antibiotic associated diarrhoea in children with respiratory infections: a randomized study. Journal Pediatric 104:1-4.

Bin-Nun A, Bromiker R, Wilschanski M, 2005. Oral probiotics prevent necrotizing enterocolitis in very low birth weight neonates. Journal Pediatric $147: 192-6$

Cavazzoni V, A Adami and C Castrovilli, 1998.Performance of broiler chickens supplemented with Bacillus coagulans as probiotic. Br. Poult. Sci., 39: 526-529

Cortes CA, Avila GE, Casaubon HMT and Carillo DS, 2000. The effect of Bacillus toyoi onbroiler performance. Veterinaria Mexico, 31:301-308.

Correa NB, Peret Filho LA, Penna FJ, Lima FM, Nicoli JR (2005). A randomized formula controlled trial of Bifidobacterium lactis and Streptococcus thermophilus for prevention of antibioticassociated diarrhoea in infants. J Clin Gastroenterol 39:385-389.

Dahouenon-Ahoussi E, Degnon R G, Adjou ES, Sohounhloue DCK, 2012. Stabilisation de la 


\section{N'tcha et al. . J. Appl. Biosci. Indigenous knowledge associated with the production of starters culture used}

to produce Beninese opaque sorghum beers

bière produite à partir de matières amylacées locales (Sorghum bicolor et Musa acuminata) par adjonction de l'huile essentielle de Cymbopogon citratus. In Journal of Applied Biosciences 51: 3596-3607, ISSN 1997-5902.

Djanan D, Mbayhoudel K, Nandoum M, 2002. Organisation des unités de transformation artisanale en zone de savanes: Cas de la transformation du sorgho en bière locale bili-bili à Moundou au Tchad. Actes du colloque, 27-31 mai, Garoua, Cameroun. 6p

Food and Agriculture Organization of the United Nations (FAO). Available online: http://faostat.fao.org/ (accessed on 12 May 2014).

Glover RLK, Abaidoo RC, Jakobsen M, Jespersen L (2005). Biodiversity of Saccharomyces cerevisae isolated from a survey of pito production sites in various parts of Ghana. Systematic Appl. Microbiol., 28: 755- 761.

Greppi A, Rantisou Ki, Padonou W, Hounhouigan J, Jespersen L, JAKOBSEN M, Cocolin L, 2013. Yeast dynamics during spontaneous fermentation of mawè and tchoukoutou, two traditional products from Benin. International journal of food microbiology 165: 200-207

Gunes $H$, Cerit $H$ and Altinel A, 2001. Effect of preprobiotic (fermacto-500) on the yield characteristics of broiler chickens. Veteriner Fakultesi Dergisi Istanbul, 27: 217-228.

Haggblade S, Holzapfel H (1989). Industrialization of Africa's indigenous beer brewing. In Steinkraus $\mathrm{KH}$ (ed.), Industrialization of indigenous fermented foods. Marcel Dekker Inc., New York, pp. 191- 283.

Kabir SML, Rahman MM, Rahman MB, Rahman MM and Ahmed SU, 2004. The Dynamics of Probiotics on Growth Performance and Immune Response in Broilers. International Journal of Poultry Science 3 (5): 361-364.

Kayodé, APP, Deh DC, BaBa-Moussa L, Kotchoni SO, Hounhouigan JD, 2012 Stabilization and preservation of probiotic properties of the traditional starter of African opaque bièresorghum beer. Afr. J. Biotech 11: 77257730.

Kayodé APP, Vieira-Dalodé G, Kotchoni SO, Linnemann AR, Hounhouigan JD, van Boekel MAJS and Nout MJR, 2011. Diversity of yeasts involved in the fermentation of tchoukoutou, an opaque sorghum beer from Benin. African Journal of Microbiology Research. 5: 2737-2742
Kayodé, APP, Adégbidi A, Linnement AR, Nout, MJR, Hounhouigan DJ, 2005. Quality of farmer's varieties of sorghum and derived foods as perceived by consumers in Benin. Ecology of food and Nutrition 44: 271-294.

Klaenhammer, T.R. and W.M. Russell. 2000. Species of the Lactobacillus acidophilus complex. Encyclopedia of Food Microbiology, Volume 2. Robinson, R.K, Batt, C., and Patel, P.D. (eds). Academic Press San Diego, pp. 1151-1157.

Kotowska M, Albrecht P, Szajewska H, 2005. Saccharomyces boulardii in the prevention of antibiotic-associated diarrhoea in children: a randomized double-blind placebo-controlled trial. Aliment Pharmacol Ther 21:583-90.

Lin $\mathrm{HC}$, Hsu CH, Chen HL, et al 2008. Oral probiotics prevent necrotizing enterocolitis in very low birth weight preterm infants: a multicenter, randomized, controlled trial. Pediatrics 122: 693-700.

Lin HC, Su BH, Chen AC, et al 2005. Oral probiotics reduce the incidence and severity of necrotizing enterocolitis in very low birth weight infants. Pediatrics 115:1-4.

Mahajan P, Sahoo J and Panda PC, 1999. Effects of probiotic feeding and seasons on the growth performance and carcass quality of broilers. Ind. J. Poult. Sci., 34: 167-176.

Michodjèhoun-Mestres L, Hounhouigan, Dossou DJ, and Mestres J, 2005. Physical, chemical and microbiological changes during natural fermentation of Gowe, a sprouted or nonsprouted sorghum beverage from West Africa. Afr J Biotechnol4, 487-496

Moreira MR, Ponce AG, de Valle CE, Roura SI, 2005. Inhibitory parameters of essential oils to reduce a foodborne pathogen. LebensmittelWissenschaft und -Technologie-LWT, 38: 565570.

Odunfa SA (1985). African fermented foods. In Wood, B.J.B. (ed.), Microbiol of Fermented Foods. Elsevier Applied Science, London, UK, pp. 167195.

Ruszczyński M, Radzikowski A, Szajewska H, 2008. Clinical trial: effectiveness of Lactobacillus rhamnosus (strains $\mathrm{E} / \mathrm{N}, \mathrm{Oxy}$ and Pen) in the prevention of antibiotic-associated diarrhoea in children. Aliment Pharmacol Ther 28:154-161.

Shoeib, HK and AH, Madian, 2002. A study on the effect of feeding diets containing probiotics (Pronifer and biogen) on growth performance, 
N'tcha et al. . J. Appl. Biosci. Indigenous knowledge associated with the production of starters culture used to produce Beninese opaque sorghum beers

intestinal flora and haematological picture of broiler chicks. Assiut Vet. Med. J., 47: 112-125.

Shukla S, Shukla A, Mehboob S, Guha S, 2011. Metaanalysis: the effects of gut flora modulation using prebiotics, probiotics and synbiotics on minimal hepatic encephalopathy. Aliment Pharmacol Ther 33: 662-671.

Szajewska H, Mrukowicz J (2005). Meta-analysis: nonpathogenic yeast Saccharomyces boulardii in the prevention of antibiotic-associated diarrhoea. Aliment Pharmacol Ther 22: 365-372.

Szajewska H, Skorka A, Dylag M 2007. Meta-analysis: Saccharomyces boulardii for treating acute diarrhoea in children. Aliment Pharmacol Ther; 25:257-264.

Vanderhoof JA, Whitney DB, Antonson DL, Hanner TL, Lupo JV, Young RJ 1999. Lactobacillus $G$ in the prevention of antibiotic-associated diarrhoea in children. JPediatr 135: 564-568.

Vieira-Dalodé G, Jespersen L, Hounhouigan J, Moller PL, Nago CM and Jakobsen M, 2007. Lacticacid bacteria and yeasts associated with gowe' production from sorghum in Bénin. Journal of Applied Microbiology. 103: 342-349

Zangué SC, Desobgo F, Naponni Y,Emmanuel J, 2013. Caractérisation des moûts et bières du sorgho Safrari houblonnés avec Vernonia amygdalina et Nauclea diderrichii. International Journal of Innovation and Applied Studies, 22: 83-91Zeller, F.J. Sorghum (Sorghum bicolor L. Moench): Utilization, genetics, breeding. Bodenkultur, 51 : 71-85. 